\title{
INTEGRATED IMPACT ASSESSMENT OF AGRICULTURAL GHG ABATEMENT MEASURES
}

Kaspars Naglis-Liepa ${ }^{1}$, Dr. oec; Dina Popluga ${ }^{2}$, Dr.oec.; Arnis Lenerts ${ }^{3}$, MBA.; Peteris Rivza ${ }^{4}$ Dr.ing., Dzidra Kreismane ${ }^{5}$, Dr.agr.

1,2,3 Latvia University of Life Sciences and Technologies, Faculty of Economics and Regional Development; ${ }^{4}$ Latvia University of Life Sciences and Technologies, Faculty of Information Technology; ${ }^{3}$ Latvia University of Life Sciences and Technologies, Faculty of Agriculture

Abstract. GHG emission reduction in the non-ETS (emission trading system) sector is a relevant component of environmental policies for the next programming period. Specific policy matters of the next programming period are unclear, yet in general, it is clear that the reduction of emissions or at least the introduction of emission abatement measures are binding on agriculture. A popular way how to analyse GHG emission abatement measures is to use a marginal abatement cost curve (MACC) that ranges the measures according to their costs and emission reduction potential. Such a research study has been done and the measures have been analysed in Latvia. A MACC, however, gives a relative notion of the effects of GHG emission abatement measures on sustainable development in Latvia. The research aim is to analyse the effects of GHG emission abatement measures on sustainable development in Latvia. The key instrument of the present research is Integrated Impact Assessment; according to it, experts from various fields identify the effects of GHG emission abatement measures on the economy, the environment and social development, determining its vector (positive/negative) as well as effect intensity (on a scale from 1 to 3 ). The results showed that some measures, e.g. promotion of biogas production, could have a negative effect in some sustainability sub-dimensions, yet overall the GHG emission abatement measures make positive and significant effects not only on the environment but also on sustainability at large. At the same time, it has to be taken into consideration that the effects identified by the experts are indicative and more research has to be done to make a more accurate assessment.

Key words: marginal abatement cost curve, integrated impact assessment, greenhouse gases, agriculture. JEL code: F64; G28; O44; P28

\section{Introduction}

Environmental preservation is one of the EU multifaceted policy priorities that influences all the other policies, among them agricultural (European Commission, 2011). Agriculture plays an essential role in environmental preservation and in shaping climate policies. The agriculture of Latvia is the second largest source of greenhouse gas (GHG) emissions, accounting for $24.2 \%$ of the total emissions produced in the country (Latvia's National Inventory Report, 2017). All the sectors of the economy have to contribute to the reduction of GHG emissions. Research studies (Cilinskis et al., 2017) have analysed various instruments that reduce emissions from the non-ETS sector. It has been found that there are great opportunities for GHG emission reduction ( $80 \%)$ in Latvia by means of carbon tax, subsidies for solar technologies and funding for energy efficient renovation. However, reducing agricultural GHG emissions is a complicated problem. It is determined by the source of GHG emissions, which is mainly the feed fermentation process in the intestines of animals $\left(\mathrm{CH}_{4}\right)$; in 2015 , it accounted for $31.3 \%$ of the total agricultural emissions. Fertiliser application $\left(\mathrm{N}_{2} \mathrm{O}\right)$ and organic soil use $\left(\mathrm{N}_{2} \mathrm{O}, \mathrm{CO}_{2}\right)$ made up $60.5 \%$, while manure management $\left(\mathrm{CH}_{4} ; \mathrm{N}_{2} \mathrm{O}\right)$ comprised $7.2 \%$ of the total (Latvia's National Inventory Report, 2017). The simplest way is to diminish the so-called activity data or to reduce the number of agricultural animals and fertiliser application and to limit activity in organic soils. However, such an approach is in contradiction to the agricultural development goals of Latvia (Latvijas Bioekonomikas strategija 2030, 2017; Pilvere et. al., 2017) and current trends (Pilvere I. et al., 2016; Nipers, A., et. al., 2017), as it envisages a considerable increase in agricultural output. Another alternative is the change of farming practices, which could raise the efficiency of the factors of production and/or 
reduce the release of emissions; the goal of such measures is to reduce relative GHG emissions per unit of agricultural output. This approach is generally accepted in the EU (FrelihLarsen A. et al., 2014). The most frequently used kind of analysis to examine GHG emission abatement measures is the so-called marginal abatement cost curve, which is a histogram that compares the measures according to GHG emission reduction potential and measure introduction and maintenance costs. The research aim is to analyse the effects of GHG emission abatement measures on sustainable development in Latvia. The object of the research is GHG emission abatement measures.

MACC. MAC curves are used in France (Pellerin S. et al., 2013), Ireland (Schulte R. et al., 2012), Great Britain (Spadavecchia L., 2014) as well as in other countries. Overall, one can find that the approaches and solutions are diverse (Eory V. et al., 2018). Latvia also constructs MAC curves for its agriculture (Popluga, D., et.al, 2017). In general, a MACC is a very useful instrument for an analysis of GHG emission abatement measures, yet it has limited opportunities to give a comprehensive insight into the effects on economic activity as a whole, as it does not have parameters of the social, economic as well as natural environments. A solution could be a combination of a MACC with Integrated Impact Assessment (IIA).

Integrated Impact Assessment. IIA is a policy analysis instrument that allows identifying the multifaceted effect of policy measures. The instrument is not new and, of course, has several subkinds.

Integrated impact assessment is a popular instrument in strategic and policy decision-making, which allows identifying the effect of a planned or unplanned strategic measure or a policy. The general form of IIA encompasses dimensions being typical of a sustainable development process: social, environmental and economic (Santoyo-Castelazo, Azapagic, 2014), yet it is possible to view any process through the prism of the fourth dimension: a) equality and diversity; b) health and prosperity; c) the environment; d) the economy (Fife Council, 2015). Impact assessment is a set of logical steps to be followed when you prepare policy proposals. It is a process that prepares evidence for political decision-makers on the advantages and disadvantages of possible policy options by assessing their potential impacts. It is also stressed that impact assessment is an aid to political decision-making, not a substitute for it, and although many actors may be involved in an impact assessment, the lead service remains fully responsible for its quality (European Commission, 2009). IIA represents a diversity of methodological approaches. There is the ex-ante and the ex-post approach with regard to the occurrence of an event researched. The first approach identifies the effect of a potential event on the subject researched, whereas the second one analyses the effect of an implemented policy or measure. The ex-ante approach is the most popular, as it is important for the introduction of a measure to identify a broader range of the consequences of it, while being aware and reducing any potential negative effect in advance, as well as the positive effect is increased by the opportunities for financing the measure and by the link with other policies. The EC vice-President, Frans Timmermans, points out that IIA may play an enhanced role within the Juncker Commission, as well as adds that it is necessary to enhance the IIA system, focusing on ex-ante assessment as well (European Parliament, 2015). Different policies could require a specific perspective on policy effects, therefore the following kinds of assessment have been developed: social impact assessment, health impact assessment (Milner S.J. et al., 2005), environmental impact assessment (Dendena B., 2015), sustainable assessment (Sala S., 2015) and others. Aledo-Tur with his colleagues has analysed social impact assessment (SIA) 
from the multidimensional paradigm perspective and can creatively, by means of six questions, characterise the SIA from the methodological, theoretical, government involvement, epistemological, ontological and axiological perspectives. He has concluded that the SIA has to encompass as much precise potential effects of a measure as possible, which could specify the potential unjust social reality, supplementing the SIA with cross-cutting elements, contributions from regional science and spatial analysis (Aledo-Tur J., 2017). The methodological approach represents the so-called expert evaluation method, where the experts are measurers of integral effects (Sala et al., 2015), some mathematical model is employed, agricultural IIA models and climate change models are analysed (Britz W. et al., 2012), or it is a combination of both approaches (Brouwer R., van Ek R., 2004).

In summary, IAA is a popular and widely used instrument for assessing the effects of policy measures based on a variety of approaches, depending on the purpose of the assessment.

The research aim is to analyse the effects of GHG emission abatement measures on sustainable development in Latvia.

\section{Method.}

Regardless of the variations of a method, three tasks have to be performed:

- identification of economic, social and environmental effects of a policy; why and who are involved;

- identification of the most essential effects (often qualitative methods are employed);

- a detailed analysis of the most essential effects (quantitative/expected gain and loss monetary assessment).

A gain-loss analysis has been already performed for the GHG abatement measures within the present research, as well as GHG emission reduction potential was estimated, which is represented by a MACC for the GHG abatement measures for the agriculture of Latvia. Accordingly, an IIA might be considered an extension or a further derivative of the MACC. The IIA process involves five steps: a) identification of the need for an assessment of an effect; b) identification of the interests of social groups involved and the selection of experts; c) creation of a table for the assessment of the effect to be filled in by the experts; d) development of recommendations; e) familiarisation of policy makers with the results. The specifics of this research methodology are presented below.

Identification of the need for an assessment of an effect. As mentioned above, GHG emission abatement measures could cause multifaceted externalities, e.g. increase animal welfare, increase the population of pests, contribute to higher agricultural land market prices etc. As regards the practical introduction of measures, it is required to identify and take into account the measures for the purpose of setting conditions for the measure introduction. Identification of the interests of social groups involved and the selection of experts. The quality of expert selection directly affects the quality of research; therefore, the experts involved have to represent national institutions: the Ministry of Environmental Protection and Regional Development and the State Plant Protection Service, farmers: the Farmers Parliament (large farms) and the Latvian Farmers Union (small and organic farms) and agricultural experts in agronomy and livestock husbandry. The experts were familiarised with the purpose and construction specifics of a MAC curve and the measures analysed in the curve. Creation of a table for the assessment of the effect to be filled in by the experts. The groups of influencing factors are traditional and encompass the usual sustainability dimensions: the environment, the economy and the society. Some sub-dimensions were selected using the 
available methodological guidelines (Fife Council, 2015; European Commission, 2009), as well as the externalities of measures identified in the above-mentioned seminars on MACC construction. The assessment involves three levels: a) identification of whether a measure makes an effect on a particular sub-dimension of sustainability; b) identification of whether the effect is positive or negative; c) identification of the intensity of the effect (on a scale from 1 - weak to 3 - strong). Such an approach is employed in urban analysis (Andersson-Skold Y., 2015). The table was filled in during an in-person meeting of the experts who discussed every measure individually, yet the IIA table was filled in by every expert individually, which enabled the experts to consider every measure from different perspectives, while having the right to express their own opinions. Development of recommendations. The recommendations were drawn up based on the summary table with the experts' ratings as well as the discussion. It has to be noted that in some cases the experts' ratings differed, which is understandable, as they represented diverse social groups; for this reason, the research employed the multi-step aggregation approach. Both the mode, the average and the median (useless due to a small sample) were calculated for every effect of every measure on every sustainability sub-dimension; a simultaneous comparison allowed relatively objectively aggregating the experts' ratings. Familiarisation of policy makers with the results. The research results were presented as the MACC extension for GHG emissions from the agriculture of Latvia for national agricultural policy makers: the Ministry of Agriculture, the Latvian Rural Support Service, those working on the Rural Development Programme as well as the Consultant Organisation, the Latvian Rural Advisory and Training Centre (LLKC), the Union of Farmer Organisations and the Latvian Agricultural Organisation Cooperation Council (LOSP).

\section{Research results and discussion}

The research results are summarised in Table 1 , in which the potential sustainability subdimensions are arranged horizontally and the GHG emission abatement measures are arranged vertically. The experts' ratings are shown by means of colours and signs: grey means a positive effect, darker grey means a negative effect, white - no effect; the signs show the intensity of the effect, see below. 
Summary of integral effects of GHG emission abatement measures

\begin{tabular}{|c|c|c|c|c|c|c|c|c|c|c|c|c|c|c|c|c|c|c|c|c|c|c|c|}
\hline \multirow[b]{2}{*}{$\begin{array}{l}\text { Measure/ } \\
\text { Impact } \\
\text { criteria }\end{array}$} & \multicolumn{10}{|c|}{ Economic aspects } & \multicolumn{7}{|c|}{ Social aspects } & \multicolumn{6}{|c|}{ Environmental aspects } \\
\hline & 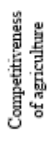 & 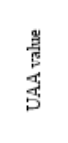 & 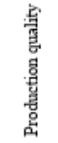 & 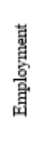 & 吉 & 营 & 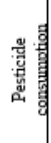 & 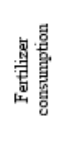 & 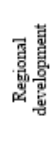 & 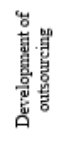 & 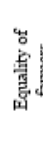 & 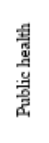 & 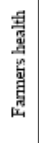 & 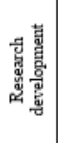 & 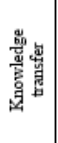 & 鄫县 & 惫 & 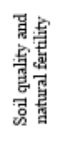 & 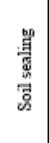 & 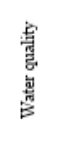 & 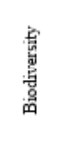 & 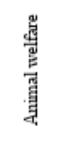 & 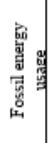 \\
\hline $\begin{array}{l}\text { Introduction of } \\
\text { perennial grasses } \\
\text { in organic arable } \\
\text { soils }\end{array}$ & $\checkmark$ & $d s d$ & $\checkmark \checkmark \checkmark$ & $\circ$ & $\circ$ & $\circ$ & 0 & $\circ$ & 0 & $\circ$ & 0 & $\circ$ & $\circ$ & 0 & $\circ$ & 0 & $\circ$ & $\Delta \checkmark v$ & 0 & $\Delta d$ & 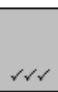 & $\circ$ & 0 \\
\hline $\begin{array}{l}\text { Nitrogen fixation } \\
\text { (legume plants in } \\
\text { crop rotation) }\end{array}$ & $\checkmark$ & $d r$ & $\checkmark$ & 0 & 0 & 0 & $\checkmark$ & $d s d$ & 0 & 0 & 0 & 0 & 0 & $r$ & $r$ & 0 & 0 & 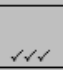 & $r v$ & $\Delta d$ & $\checkmark$ & 0 & 0 \\
\hline $\begin{array}{l}\text { Fertilisation } \\
\text { planning }\end{array}$ & $s d$ & $a d$ & $\checkmark \checkmark$ & $\checkmark$ & $\circ$ & $\circ$ & 0 & $\checkmark \checkmark \checkmark$ & $\circ$ & $\checkmark$ & $\circ$ & $\checkmark$ & $\circ$ & $\checkmark r$ & $r$ & $\circ$ & $\circ$ & $d r$ & $\checkmark$ & $\checkmark$ & $\circ$ & $\circ$ & $\checkmark$ \\
\hline $\begin{array}{l}\text { Promotion of } \\
\text { biogas production }\end{array}$ & 0 & 0 & 0 & $r$ & 0 & 0 & 0 & 0 & $r$ & $r$ & $r$ & 0 & 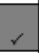 & $r$ & $\Delta d$ & $r$ & 0 & 0 & $\checkmark$ & 0 & 0 & 0 & 0 \\
\hline $\begin{array}{l}\text { Planning feed } \\
\text { rations }\end{array}$ & $d r$ & $\circ$ & $\checkmark r$ & $\circ$ & $\circ$ & $\circ$ & $\circ$ & $\circ$ & $\circ$ & $\checkmark$ & $r$ & $\circ$ & $\circ$ & $\checkmark$ & $\checkmark$ & $\circ$ & $\circ$ & $\circ$ & $\circ$ & $\circ$ & $\circ$ & 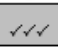 & $\circ$ \\
\hline $\begin{array}{l}\text { Solid-liquid } \\
\text { separation of } \\
\text { livestock manure }\end{array}$ & $\circ$ & $\circ$ & $\circ$ & $\checkmark$ & 0 & $\circ$ & $\circ$ & $\circ$ & $\circ$ & $\circ$ & $\circ$ & $\circ$ & $\circ$ & $\checkmark$ & $\checkmark$ & $\circ$ & $\circ$ & $\circ$ & $\circ$ & $\checkmark$ & $\circ$ & $\circ$ & 0 \\
\hline $\begin{array}{l}\text { Enrichment of } \\
\text { feed with fats }\end{array}$ & 0 & 0 & $r$ & 0 & 0 & 0 & 0 & 0 & 0 & 0 & 0 & 0 & 0 & $r$ & 0 & 0 & 0 & 0 & 0 & 0 & 0 & $\checkmark$ & 0 \\
\hline $\begin{array}{l}\text { Growing green } \\
\text { manure crops }\end{array}$ & $\circ$ & $d r$ & 0 & 0 & 0 & 0 & 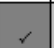 & 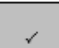 & $\circ$ & $\circ$ & $r$ & 0 & 0 & $\checkmark$ & 8 & 0 & 0 & 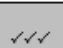 & 0 & 8 & $\checkmark$ & 0 & 0 \\
\hline Minimum tillage & $\checkmark$ & $\checkmark$ & $\circ$ & $\checkmark$ & 0 & $\circ$ & $\circ$ & $\circ$ & 은 & 0 & 0 & 0 & $\circ$ & $\checkmark$ & $\checkmark r$ & $\circ$ & $\circ$ & $\checkmark$ & $r$ & $\checkmark$ & $\checkmark$ & $\circ$ & 0 \\
\hline $\begin{array}{l}\text { Direct } \\
\text { incorporation of } \\
\text { organic fertilisers } \\
\text { in soil }\end{array}$ & $\checkmark$ & $\circ$ & $\checkmark$ & $\circ$ & $\circ$ & $\circ$ & $\circ$ & $\checkmark$ & $\circ$ & $\checkmark$ & $\circ$ & $\circ$ & $\checkmark$ & $\checkmark$ & $\checkmark \checkmark$ & $\circ$ & $\checkmark$ & $\checkmark \checkmark$ & $\circ$ & $\checkmark$ & $\circ$ & $\circ$ & $\circ$ \\
\hline $\begin{array}{l}\text { Maintenance of } \\
\text { amelioration } \\
\text { systems }\end{array}$ & $\checkmark r$ & $\Delta \checkmark r$ & $\circ$ & $\checkmark$ & $\circ$ & $\circ$ & $\circ$ & $\circ$ & $\checkmark r$ & $\checkmark \checkmark \checkmark$ & $\checkmark$ & $\circ$ & $\circ$ & $\checkmark$ & $\circ$ & $\checkmark$ & $r \checkmark r$ & $\Delta \checkmark r$ & $\circ$ & $\checkmark$ & $\checkmark$ & $\circ$ & $\circ$ \\
\hline $\begin{array}{l}\text { Precision fertiliser } \\
\text { application }\end{array}$ & $\begin{array}{c}r \\
1 \\
1\end{array}$ & $\checkmark$ & $\checkmark \checkmark$ & $\checkmark r$ & 0 & $\circ$ & $\circ$ & $\checkmark \checkmark \checkmark$ & $\checkmark r$ & $\checkmark$ & $\circ$ & $\checkmark$ & $\checkmark$ & $\checkmark \checkmark \checkmark$ & $\checkmark r$ & 0 & $\circ$ & $\circ$ & $\circ$ & $\checkmark \checkmark$ & $\circ$ & $\circ$ & $\checkmark$ \\
\hline $\begin{array}{l}\text { Application of } \\
\text { nitrification } \\
\text { inhibitors }\end{array}$ & $\circ$ & $\circ$ & $\checkmark$ & $\circ$ & 0 & $\circ$ & $\circ$ & $\checkmark$ & $\circ$ & $\circ$ & $\circ$ & $\checkmark \checkmark$ & $\circ$ & $\checkmark$ & $\checkmark$ & 0 & $\circ$ & $\circ$ & $\circ$ & $\checkmark \checkmark \checkmark$ & $\circ$ & $\circ$ & 0 \\
\hline $\begin{array}{l}\text { Intensive grazing } \\
\text { (frequent } \\
\text { livestock rotation } \\
\text { in pastures) }\end{array}$ & $\circ$ & 0 & $\checkmark$ & $\Delta d$ & 0 & 0 & $\circ$ & $\checkmark$ & $\circ$ & 0 & $\circ$ & $\circ$ & $\circ$ & $\checkmark \checkmark$ & $\checkmark$ & $\checkmark$ & $\circ$ & $\circ$ & $\checkmark$ & $\circ$ & $\checkmark$ & $\checkmark \checkmark \checkmark$ & $\checkmark$ \\
\hline $\begin{array}{l}\text { Enhancement of } \\
\text { the quality of feed }\end{array}$ & $d_{d}$ & 0 & $\checkmark d$ & 0 & 0 & 0 & 0 & 0 & $r$ & 0 & 0 & $r$ & 0 & $\checkmark r$ & $r$ & 0 & 0 & 0 & 0 & 0 & 0 & $\Delta d$ & 0 \\
\hline $\begin{array}{l}\text { Liming acidic } \\
\text { soils }\end{array}$ & $\begin{array}{c}r \\
r \\
r \\
d\end{array}$ & 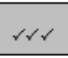 & $\checkmark r d$ & $\circ$ & 0 & $\circ$ & $\circ$ & $\checkmark$ & $\checkmark$ & $\Delta r$ & $\circ$ & $\checkmark$ & $\circ$ & $\checkmark$ & $\checkmark r$ & $\checkmark$ & $\circ$ & 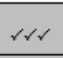 & $\checkmark$ & $\checkmark$ & $\circ$ & $\checkmark$ & $\checkmark$ \\
\hline $\begin{array}{l}\text { Extending the } \\
\text { grazing season }\end{array}$ & $d r$ & 0 & $\Delta d$ & $\checkmark$ & 0 & 0 & 0 & 0 & 0 & 0 & 0 & 0 & 0 & $\checkmark$ & $\checkmark$ & 0 & 0 & $\checkmark$ & 0 & 0 & 0 & $\Delta \checkmark \checkmark$ & 0 \\
\hline
\end{tabular}

Denotations: $\square$ - positive impact; $\square$ - negative impact; $O$ - measure don't effect analysed criteria; $\checkmark$ - impact intensity $(\checkmark-$ weak, $\checkmark \checkmark$ - medium, $\checkmark \checkmark \checkmark$ - strong) Source: authors' calculations

Overall, most of the measures cause positive externalities on sustainable development. An exception is the promotion of biogas production, which was negatively rated according to some sub-dimensions of all the three dimensions. Such a critical attitude could be largely due to the mechanism of unsuccessful promotion of biogas production under the energy policy of Latvia. Economic development is negatively affected by permanent grasses grown in organic soils, while at the same time making a positive effect on the quality of soil and water, as well as biodiversity. The introduction of this measure could be linked with not only the climate change policy but also the environment preservation policy, while being aware of a decrease in the total output of agricultural products. The environmental dimension could be negatively affected by the measure "intensive grazing", which results in higher fuel consumption, soil compaction and lower biodiversity; however, since the intensity of the effect is weak, it is possible to mitigate the effect by means of enhancement of practices of the measure. Almost all the measures make positive effects on research development and knowledge transfer, which makes us consider that the experts saw a lot of opportunities for enhancing the practices of the measures and the need for informative and training measures for farmers. It could be actually considered to be a strong demand for closer interaction between science and agricultural practices. It is surprising that the summary of the research results does not encompass the effects on imports and exports, although some experts noted such an effect for some measures. An explanation might be the relatively dual effect of a measure, i.e. the measure, on the one hand, reduces fertiliser imports, while on the other hand, increases imports owing to machinery and equipment imports. This means that if interpreting the 
results acquired, one has to take into consideration a possibility that a neutral sign in the table might be interpreted as an unclear effect as well. Overall, the IAA approach employed by the research gives insight into the effects of the measures in the form of "underwater stones" (negative effects) and "tailwind" (positive effects) that could be measured more accurately by employing quantitative methods or by enhancing the existing agricultural models or creating new ones through employing the IAA or the SIA approach.

\section{Conclusions, proposals, recommendations}

1) Integrated impact assessment is a popular instrument for assessing policy measures, which is characterised by a methodological, epistemological, ontological and axiological diversity and which continue developing as an important instrument in policy effect analysis for the European Commission, EU Member States and other world countries.

2) The GHG abatement measures analysed by means of a MACC for Latvia are diverse and, overall, make positive effects on sustainable development. Policy makers have to focus particularly on the measures that, along with positive effects, make also negative effects: permanent grasses grown in organic soils; promotion of biogas production; as well as intensive grazing. Solutions to the measures causing negative effects could be diverse. The measure "permanent grasses grown in organic soils" may be introduced in a broader context of policies: land use, land-use change, and forestry (LULUCF) management, biodiversity, water quality and for other climate and environmental policy purposes. The introduction of the measure "promotion of biogas production" has to be linked with the energy policy. However, the insignificant negative effects caused by the measure "intensive grazing" could be reduced by practical enhancements of the measure, e.g. by making the watering system more effective. It has to be mentioned that the above are only conceptual solutions that need to be examined and analysed.

3) IIA can effectively supplement a MACC, giving a multifaceted insight into the effects of GHG abatement measures. A more accurate assessment of an effect requires employing quantitative models, while considering whether the efforts to create a specific simulation tool are worth making or considering performing, if necessary, an additional analysis of the specific aspects of introduction of GHG abatement measures.

\section{Bibliography}

1. Aledo-Tur, J. Dominguez-Gomez, A. (2017). Social Impact Assessment (SIA) from a Multidimensional Paradigmatic Perspective: Challenges and Opportunities. Journal of Environmental Management. Vol. 195. part 1. pp. 56-61.

2. Andersson-Skold, Y., Thorsson, S., Rayner, D., Lindberg, D., Janhall, S., Jonsson, A., Moback, U., Bergman, R., Granberg, M. (2015). An Integrated Method for Assessing Climate-Related Risks and Adaptation Alternatives in Urban Areas. Climate Risk Management. Vol. 7. pp. 31-50.

3. Britz., W., van Ittersum, M., Lansink, A.O., Heckelei, T. (2012). Tools for Integrated assessment in Agriculture. State of Art and Challenges. Bio based and Applied Economics 1(2), p. 125-150.

4. Brouwer, R., van Ek, R. (2004). Integrated Ecological, Economic and Social Impact Assessment of Alternative Flood Control Policies in the Netherlands. Ecological Economics. Vol. 50. pp. 1-21.

5. Cilinskis, E., Ziemele, J., Blumberga, A., Blumberga, D., (2017). Analysis of Support Measures for Promoting Energy Efficiency and Renewables for GHG emissions Reduction in non-ETS Sector. Energy Procedia. 142/2017, pp. 2838-2843.

6. Dendena, B., Corsi, S. (2015). The Environmental and Social Impact Assessment: a Further Step Towards an Integrated Assessments Process. Journal of Cleaner Production. Vol. 108. pp. 965-977.

7. Eory, V., Pellerin, S., Garcia, G.C., Lehtonen, H., Licite, I., Mattila, H., Lund-Sorensen, T., Muldowney, J., Popluga, D., Strandmark, L., Schulte, R. (2018). Marginal Abatement Cost Curves for Agricultural Climate Policy: State of Art, Lessons Learnt and Future Potential. Journal of Cleaner Production. In Press.

8. European Commission (2009). Impact Assessment Guidelines. SEC(2009)92. Retrieved: http://ec.europa.eu/smart-regulation/impact/commission_guidelines/docs/iag_2009_en.pdf. Access: 20.01.2018. 
9. European Commission (2011). A Roadmap for Moving to a Competitive Low Carbon Economy in 2050. Communication from the Commission to the European Parliament, the Council, the European Economic and Social Committee and the Committee of the Regions. SEC(2011) 278-289 final. Retrieved: http://eurlex.europa.eu/LexUriServ/LexUriServ.do?uri=COM:2011:0112:FIN:EN:PDF. Access: 09.01.2018

10. European Parliament (2015.) How Does ex-ante Impact Assessment Work in the EU? Briefing. Better LawMaking in Action. Retrieved: http://www.europarl.europa.eu/RegData/etudes/BRIE/2015/528809/EPRS_BRI(2015)528809_EN.pdf. Access: 20.01.2018.

11. Fife Council (2015). Integrated Assessment Toolkit. Community Planning Strengthening Fife's Future. Retrieved: https://www.nhsfife.org/nhs/index.cfm?fuseaction=publication. pop\&pubid=6A1881A2-D2220D72-92F1D1BD84C2017A Access: 11.12.2017.

12. Frelih-Larsen, A., MacLeod, M., Osterburg, B., Eory, A. V., Dooley, E., Katsch, S., Naumann, S., Rees, B., Tarsitano, D., Topp, K., Wolff, A, Metayer, N., Molnar, A., Povellato, A., Bochu, J.L., Lasorella, M.V., Longhitano,D. (2014). "Mainstreaming Climate Change into Rural Development Policy Post 2013." Final report. Ecologic Institute, Berlin. Retrieved:

https://www.ecologic.eu/sites/files/publication/2015/mainstreaming_climatechange_rdps_post2013_final.pd f. Access: 15.01.2018.

13. Karanassou, M., Sala, H., Salvador, P.F. (2007). Capital Accumulation and Unemployment: New Insights on the Nordic Experience. IZA Discussion Paper, 3066. Retrieved: http://ssrn.com/abstract=1025889. Access: 16.09 .2012

14. Latvijas Bioekonomikas strategija 2030. Informativais zinojums. Latvijas Republikas Ministru kabinets (Bioeconomy Strategy of Latvia 2030. Informative report. Cabinet of the Republic of Latvia). Retrieved: http://tap.mk.gov.lv/lv/mk/tap/?pid=40433525\&mode=mk\&date=2017-12-19. Access: 12.02.2018.

15. Latvia's National Inventory Report (2017) Retrieved: http://unfccc.int/national_reports/annex_i_ghg_inventories/national_inventories_submissions/items/10116. php Access: 12.02.2018.

16. Milner, S.J., Bailey, C., Deans, J., Pettigrew, D. (2005). Integrated Impact Assessment in the UK - Use, Efficacy and future development. Environmental Impact Assessment Review. Vol. 25, issue 1. p. 47-61.

17. Nipers, A., Pilvere, I., Zēverte-Rivža, S. (2017) Projections for the Latvian dairy and beef sector. In: 16th International scientific conference "Engineering for rural development": proceedings, vol. 16, p. 546-554.

18. Ortiz, R. A. and Markandya A. (2009). Integrated Impact Assessment Models with an Emphasis on Damage Functions: a Literature Review. BC3 Working Paper Series 2009-06. Basque Centre for Climate Change (BC3). Bilbao, Spain.

19. Pellerin, S., Bamiere, L., Angers, D., Beline, F., Benoit, M., Butault, J. P., Chenu, C., Colnenne David, C., De Cara, S., Delame, N., Dureau, M., Dupraz, P., Faverdin, P., Garcia Launay, F., Hassouna, M., Henault, C., Jeuffroy, M. H., Klumpp, K., Metay, A., Moran, D., Recous, S., Samson, E. and Savini, I. (2013). How Can French Agriculture Contribute to Reducing Greenhouse Gas Emissions? Abatement Potential and Cost of Ten Technical Measures, INRA.

20. Pilvere, I., Nipers, A., Zeverte-Rivza, S., Krievina, A., Kozlinskis, V., Upite, I., (2016) Lauksaimniecibas attistibas prognozesana un politikas scenariju izstrade lidz 2050. gadam. Projekta atskaite (Agricultural Development Projections and Policy Scenario Development up to 2050. Project report). Retrieved: https://www.zm.gov.Iv/public/ck/files/Lauksaimniecibas \%20attistibas \%20prognozes \%202050.pdf. Access: 10.01.2018.

21. Pilvere, I., Nipers, A., Silamikele, I., Mickewiez B. (2017) Development opportunities for the bioeconomy in Latvia. In: 4th International multidisciplinary scientific conference on social sciences and arts SGEM 2017: conference proceedings, Book 1: Modern Science, vol. 4.: Economics and Tourism, p. 229-236.

22. Popluga D., Naglis-Liepa K., Lenerts A., Rivza P. (2017). Marginal abatement cost curve for assessing mitigation potential of Latvian agricultural greenhouse gas emissions: case study of crop sector. In: 17th International multidisciplinary scientific GeoConference SGEM 2017: conference proceedings, Vol.17: Energy and clean technologies; Issue 41: Nuclear technologies. Recycling. Air pollution and climate change, p. 511518.

23. Sala, S., Ciuffo, B., Nijkamp, P. (2015). A Systemic Framework for Sustainable Assessment. Ecological Economics. Vol. 119. pp. 314-325.

24. Santoyo-Catelazo, E., Azapagic, A. (2014). Sustainability Assessment of Energy Systems: Integration Environmental, Economic and Social Aspects. Journal of Cleaner Production. Vol. 80. pp. 119-138.

25. Schulte, R. P., Crosson, P., Donnellan, T., Farrelly, N., Finnan, J., Lalor, S. T., Lanigan, G., O'Brien, D., Shalloo, L. and Thorne, F. Schulte, R. P. and Donnellan, T. (ed) (2012). A Marginal Abatement Cost Curve for Irish Agriculture, Teagasc.

26. Spadavecchia, L. (2014). Evidence Review: Agricultural GHG Emissions Abatement. An Appraisal and Update of Agricultural Marginal Abatement Cost Curve Analyses. DRAFT Defra. 